\title{
POTENSI, PENGEMASAN DAN MODEL SALURAN DISTRIBUSI PEMASARAN PAKET WISATA PEDESAAN DI DESA BATUBULAN KANGIN
}

\author{
Ni Kadek Devi Somiari ${ }^{1}$, I Putu Sudana ${ }^{2}$, NGAS. Dewi ${ }^{3}$ \\ Email: devisomiari@gmail.com ${ }^{1}$, sudanaputu@yahoo.com ${ }^{2}$, susrami_ipw@unud.ac.id ${ }^{3}$ \\ ${ }^{1,2,3}$ Program Studi Industri Perjalanan Wisata, Fakultas Pariwisata, Universitas Udayana
}

\begin{abstract}
Rural tourism development is very important to do because it is in line with the trend of sustainable tourism and the needs of new tourists. Batubulan Kangin Village has tourism potentials to develop as a rural tourism destination through a rural package tour. Mapping the village potential is very important to do to form a tour package. Marketing distribution channels need to be designed to reach the tourists as the consumer. The data were collected through observation, interviews, literature studies, and documentation. The informants were determined by purposive sampling and used descriptive qualitative technique to analysed the data. The result of this research shows that the natural attraction of Batubulan Kangin Village is rice fields scenery. The cultural attraction consists of authentic Balinese Cooking Class, offerings making class, and the village's structure. Artificial attractions consist of a rice skin peeling process, wood carving gallery, Balinese Dance Studio, elementary school, Jaje Sirat House Production, Dug-Dug Mong Statue, and Balinese house. The amenities consist of food and beverage provision by Tumang Cooking Class. The accessibility is very adequate, and the ancillary service is potentially provided by the local communities. That potential can be packaged into a Halfday Cultural Cycling Tour Around Batuyang Village and 3 Days 2 Nights Tour Exploring the Authentic Way of Batuyang Village's Life. The tour packages are managed and marketed directly via the internet, as well as collaborating with tourism drivers, tour guides, Five Pillar Experiences, GODEVI, and market places as the indirect marketing distribution channel.
\end{abstract}

\begin{abstract}
Abstrak: Pengembangan wisata pedesaan sangat penting untuk dilakukan karena sejalan dengan tren pariwisata berkelanjutan dan kebutuhan new tourist. Desa Batubulan Kangin merupakan salah satu desa dengan potensi desa yang dapat dikembangkan sebagai wisata pedesaan. Pemetaan potensi desa sangat penting untuk dilakukan sehingga sebuah paket wisata pedesaan dapat dikemas. Setelah paket wisata dikemas, saluran distribusi pemasaran perlu dirancang agar paket wisata dapat sampai pada konsumen secara luas. Teknik pengumpulan data dalam penelitian ini adalah observasi, wawancara, studi pustaka dan dokumentasi. Teknik penentuan informan dalam penelitian ini adalah purposive sampling. Teknik analisis yang digunakan adalah deskriptif kualitatif. Hasil penelitian menunjukan bahwa Desa Batubulan Kangin memiliki potensi atraksi alam berupa pemandangan persawahan. Atraksi budaya berupa aktivitas belajar memasak makanan khas Bali, belajar membuat canang maupun gebogan, dan struktur desa Bali. Atraksi buatan berupa selip padi, galeri wood carving, sanggar tari, sekolah dasar, Rumah Produksi Jaje Sirat, Patung Dug-Dug Mong, serta struktur rumah adat Bali. Potensi amenities yang dimiliki adalah penyediaan makanan dan minuman oleh masyarakat lokal melalui Lembaga Tumang Cooking Class. Accesibility yang sangat memadai, dan ancillary service disediakan oleh masyarakat lokal dalam lembaga Sri Bali Tour-Tumang Cooking Class dan Yayasan Celekontong Mas Batuyang. Potensi tersebut dapat dikemas menjadi Half Day Cultural Cycling Tour Around Batuyang Village dan paket wisata 3 Days 2 Nights Tour Exploring the Authentic Way of Batuyang Village's Life. Paket wisata tersebut dikelola dan dipasarkan langsung melalui internet, dan menggandeng sopir pariwisata Bali, pemandu wisata Bali, Five Pillar Experiences, GODEVI dan market place sebagai agen saluran distribusi pemasaran tak langsung.
\end{abstract}

Keywords: tourism potential, rural tourism package packaging, marketing distribution channels. 


\section{PENDAHULUAN}

Kementrian Pariwisata Republik Indonesia mencetuskan target pengembangan 2000 desa wisata di seluruh Indonesia (Patriella, 2019). Salah satu daerah yang tentunya tidak luput dari pengembangan tersebut adalah Bali (Ariani, 2017). Bali telah memiliki 54 desa wisata yang tersebar di seluruh kecamatan yang ada (Statistik Pariwisata Bali, 2018 dalam Arismayanti et al., 2019). Pertumbuhan jumlah desa wisata di Bali tidak sejalan dengan perkembangannya, dimana kuantitas desa wisata di Bali tidak diiringi dengan kualitas yang bagus sehingga berdampak pada eksistensi desa wisata di Bali yang masih sangat minim.

Minimnya eksistensi desa wisata di Bali disebabkan oleh cara pandang masyarakat yang menyimpang terhadap pengembangan desa wisata, kurangnya sosialisasi dan pembinaan desa wisata bagi pemerintah desa dan masyarakat, belum terjalinnya koordinasi antar pemerintah, adanya permasalahan modal, pengelolaan kelembagaan yang kurang baik, kurangnya sumber daya manusia, kunjungan wisatawan yang kurang sehingga tidak memenuhi harapan, ekspektasi masyarakat akan hasil yang instan, pemerintah daerah yang terkesan lepas tangan, permasalahan promosi hingga kurangnya pengembangan atraksi wisata di sebuah desa (Mahagangga dkk., 2015:6).

Pengembangan atraksi wisata di sebuah desa merupakan hal yang sangat penting dilakukan untuk mendukung eksistensinya. Atraksi wisata yang dikembangkan di sebuah desa dapat pula digolongkan sebagai sebuah wisata pedesaan. Wisata pedesaan merupakan sebuah aktivitas wisata yang dikembangkan di wilayah pedesaan, dimana daya tarik utamanya merupakan keseluruhan hal yang dimiliki suatu desa, mulai dari kehidupan sosial, ekonomi, adat istiadat, arsitektur bangunan dan lain sebagainya yang merupakan potensi wisata miliki desa tersebut (Departemen Kebudayaan dan Pariwisata, 2001 dalam Dewi 2016).

Potensi wisata merupakan hal yang berkaitan erat dengan pengembangan wisata pedesaan, dimana adanya potensi wisata yang memadai yaitu memenuhi adanya 4 komponen yang terdiri dari attraction, amenities, accessibility, dan ancillary service ditambah hospitality akan memungkinkan sebuah aktivitas wisata berlangsung dan sebuah paket wisata dapat dikemas (Cooper et al. 1993 dalam
Suwena dan Widyatmaja, 2017; Spillane dalam Afriza dkk., 2017). Salah satu daerah di Bali yang memiliki potensi wisata yang besar serta dapat dikemas menjadi paket wisata adalah Kabupaten Gianyar.

Kabupaten Gianyar merupakan sebuah daerah yang sangat kental akan seni dan budaya hingga dijuluki sebagai buminya seni (Deny, 2019). Sebagai sebuah daerah yang kental akan seni dan budaya Kabupaten Gianyar menjadi salah satu kabupaten yang memiliki daerah pariwisata dengan eksistensi yang tinggi. Namun, pariwisata di Kabupaten Gianyar masih terpusat di Ubud sehingga dapat dikatakan bahwa ada ketimpangan pengembangan pariwisata di Kabupaten Gianyar (bali-travelnews.com, 2017).

Salah satu desa yang merasakan adanya ketimpangan tersebut adalah Desa Batubulan Kangin, dimana hingga saat ini belum ada pengembangan pariwisata yang dilkukan. Meskipun demikian, seorang masyarakat Desa Batubulan Kangin yang telah berkecimpung selama puluhan tahun dalam industri pariwisata yaitu Ibu Pande Putu Sriningsih melihat adanya potensi besar yang dimiliki Desa Batubulan Kangin untuk dikembangkan menjadi sebuah tujuan wisata. Melalui bisnis pariwisatanya yaitu Sri Bali Tour, beliau telah merancang sebuah aktivitas wisata berupa kelas memasak masakan tradisional Bali yang dikombinasikan dengan pengenalan struktur rumah adat Bali serta pembuatan canang dan gebogan. Aktivitas wisata yang dirancang tersebut, menurut beliau belum dikembangkan dengan maksimal, dimana pengembangannya belum mencakup keseluruh potensi yang dimiliki oleh Desa Batubulan Kangin (Hasil Wawancara, 2020).

Meskipun pengembangannya belum maksimal, Sri Bali Tour melalui aktivitas wisata yang telah dirancang tersebut, terbukti telah dapat menarik minat wisatawan untuk berkunjung ke Desa Batubulan Kangin. Data Kunjungan wisatawan ke Desa Batubulan Kangin dapat dilihat dalam Tabel 1 berikut:

Tabel 1. Kunjungan Wisatawan ke Desa Batubulan Kangin Tahun 2013-2020

\begin{tabular}{cc}
\hline Tahun & Jumlah Kunjungan \\
\hline 2013 & 1 \\
\hline 2014 & 5 \\
\hline 2015 & 12 \\
\hline
\end{tabular}




\begin{tabular}{cc}
\hline 2016 & 7 \\
\hline 2017 & 6 \\
\hline 2018 & 26 \\
\hline 2019 & 40 \\
\hline 2020 & 13 (Hingga Agustus)
\end{tabular}

Sumber: Sri Bali Tour, 2020.

Adanya kunjungan wisatawan dan adanya aktivitas wisata di Desa Batubulan Kangin dapat dijadikan sebuah tolak ukur bahwa Desa Batubulan Kangin memiliki potensi wisata yang dapat lebih dikembangkan sehingga dapat memberikan manfaat merata kepada masyarakat. Pengembangan potensi wisata melalui sebuah paket wisata pedesaan sangat tepat dan penting untuk dilakukan karena sejalan dengan tren pariwisata saat ini yaitu pariwisata berkelanjutan dan permintaan pasar new tourist yang juga beriringan dengan tren tersebut. Potensi wisata Desa Batubulan Kangin yang telah dikemas menjadi paket wisata pedesaan, memerlukan model saluran distribusi pemasaran agar dapat sampai pada konsumen dan akhirnya dapat meningkatkan kunjungan wisatawan.

Berdasarkan hal tersebut, penulis bertujuan untuk meneliti mengenai potensi, pengemasan dan model saluran distribusi pemasaran di Desa Batubulan Kangin, Sukawati, Gianyar, Bali.

\section{METODE PENELITIAN}

Penelitian ini dilakukan di Desa Batubulan Kangin karena adanya potensi wisata yang dapat dikembangkan guna mendukung program pemerintah Republik Indonesia dalam program pariwisata berkelanjutan.

Data dalam penelitian dikumpulkan melalui observasi, wawancara, studi pustaka dan dokumentasi. Informan dalam wawancara ditentukan dengan metode purposive sampling, yaitu ditentukan berdasarkan kriteria khusus yang ditetapkan penulis, dalam hal ini kriteria narasumber yang ditetapkan adalah narasumber yang memiliki wawasan mengenai Desa Batubulan Kangin, pemasaran paket wisata serta masyarakat setempat yang memiliki aktivitas unik, dimana Kepala Desa Batubulan Kangin merupakan informan pangkal. Informan kunci dari penelitian ini adalah Kepala BUMDes Batubulan Kangin, masyarakat Desa Batubulan Kangin, Five Pillar
Experiences, dan Go Destination Village. Data yang dikumpulkan selanjutnya dianalisis dengan teknik analisis deskriptif kualitatif.

\section{HASIL DAN PEMBAHASAN}

Berdasarkan penelitian yang dilakukan di Desa Batubulan Kangin, maka diperoleh hasil dan pembahasan sebagai berikut:

\section{Potensi Desa Batubulan Kangin}

Potensi wisata Desa Batubulan Kangin yang dapat mendukung pengemasan paket wisata pedesaan adalah sebagai berikut:

\section{Attraction}

Potensi attraction di Desa Batubulan Kangin terdiri dari:

\section{Atraksi Alam \\ Potensi atraksi alam Desa Batubulan Kangin yaitu pemandangan hamparan sawah yang terbentang di daerah utara, timur dan barat desa seluas 208,23 ha (Atmaja, 2020). Hamparan sawah yang paling memungkinkan untuk dinikmati oleh pengunjung adalah hamparan sawah yang terletak disepanjang Jalan Subak Belaki, berjarak $1 \mathrm{~km}$ dari Desa Celuk menuju pusat Desa Batubulan Kangin tepatnya berlokasi di sisi utara Desa Batubulan Kangin (Observasi, 2020). Selain hamparan sawah yang indah, pemandangan Gunung Agung di sisi timur serta aliran air di sepanjang jalan juga dapat menambah asrinya suasana yang disuguhkan.}

\section{Atraksi Budaya}

Potensi atraksi budaya di Desa Batubulan Kangin adalah aktivitas wisata yang disediakan oleh Sri Bali Tour-Tumang Cooking Class yaitu berupa aktivitas belajar memasak masakan khas Bali berupa Babi Guling dan Ayam atau Bebek Betutu sebagai hidangan utama yang dimasak dengan perapian tradisional. Hidangan pendamping dalam aktivitas wisata tersebut adalah lawar, jukut urab, sate lilit, pepes ayam / babi, calonpulung ayam, serta tiga jenis sambal yang terdiri dari sambal matah, sambal goreng dan sambal ulek. Aktivitas authentic Balinese cooking class tersebut berlangsung di rumah Ibu Pande Putu Sriningsih tepatnya di Dusun/Banjar Dajan Rurung. Aktivitas tersebut disediakan dalam dua sesi yaitu sesi pagi yang berlangsung pada pukul 08.30-13.30 Wita dan 
sesi sore yang berlangsung pada pukul 14.3019.20 Wita.

Potensi atraksi budaya di Desa Batubulan Kangin selanjutnya adalah struktur desa pakraman. Struktur desa pakraman di Bali sangatlah unik yaitu tersusun dari 3 unsur penting yaitu unsur Parahyangan, Palemahan, dan Pawongan. Dari ketiga unsur tersebut, yang dapat digolongkan sebagai potensi atraksi budaya adalah unsur Parahyangan dan Pawongan. Unsur Parhyangan merupakan simbol adanya hubungan antara manusia dengan sang pencipta yaitu Tuhan Yang Maha Esa / Ida Sang Hyang Widhi Wasa, dimana dalam struktur desa dilambangkan dengan adanya Pura Khayangan Tiga yang terdiri dari Pura Desa dan Pura Puseh yang berlokasi di lingkungan Banjar Puseh tepatnya di sisi utara desa yaitu merupakan stana dari Dewa Brahma dan Dewa Wisnu yang dipercaya sebagai sang pencipta dan sang pemelihara khidupan manusia dan Pura Dalem yang berlokasi di sisi selatan desa tepatnya di lingkungan Banjar Tampad, yaitu merupakan stana dari Dewa Siwa yang dipercaya sebagai sang pelebur dalam kepercayaan Hindu. Selain itu, unsur parahyangan di Desa Batubulan Kangin juga dilambangkan dengan adanya Griya tepatnya di lingkungan Banjar Kenanga dan Banjar Dajan Rurung, adanya Pura Ulun Carik yang berlokasi di Jalan Subak Belaki (sisi utara desa) yang merupakan stana Dewi Uma dan berkaitan erat dengan unsur palemahan yaitu sawah dan sistem irigasinya.

Sedangkan unsur pawongan yang merupakan lambang dari hubungan harmonis antara manusia dengan manusia dalam sebuah struktur desa adat dilambangkan dengan adanya balai banjar yang memiliki peran penting dalam proses kehidupan masyarakat desa setempat dari lahir hingga meninggal dunia, dimana masyarakat menggunakan balai banjar sebagai tempat untuk menyelenggarakan musyawarah, mempersiapkan upacara keagamaan hingga berbagai aktivitas yang memungkinkan adanya jalinan hubungan harmonis antara manusia dengan manusia.

Desa Batubulan Kangin sendiri, memiliki 9 banjar yang terdiri dari Banjar Puseh, Banjar Tangkeban, Banjar Kenanga, Banjar Tampad, Banjar Buda Ireng, Banjar Delod Rurung, Banjar Dajan Rurung, Banjar Mula, dan Banjar Batuaji.

Setiap potensi tersebut mengandung nilai budaya dan filosofis yang tinggi bagi masyarakat yang merupakan umat beragama Hindu sehingga sangat memiliki keunikan dan dapat disebut sebagai sebuah daya tarik wisata.

\section{Atraksi Buatan}

Potensi atraksi buatan di Desa Batubulan Kangin adalah adanya galeri patung kayu pahat (Wood carving) yang terletak di sisi timur desa tepatnya di area Dusun/Banjar Kenanga. Kerajinan kayu pahat yang dihasilkan adalah patung dewa-dewi, patung naga, hiasan dinding serta patung Budha. Hasil pahatan yang dihasilkan biasanya dijual ke pasar seni, pusat oleh-oleh serta diekspor kepada negara-negara luar yang memesan langsung kepada pengelola galeri.

Selain itu, Desa Batubulan Kangin sendiri memiliki lebih dari 100 orang pemahat patung kayu (Wood Carver) yang beraktivitas aktif dari pagi hingga sore (07.00-17.00 Wita) hari. Banyaknya masyarakat yang memiliki keahlian memahat menjadi potensi yang besar berkaitan dengan pengadaan aktivitas wisata terutama belajar memahat kayu (Wood Carving Class) bagi wisatawan.

Potensi atraksi wisata buatan selanjutnya adalah adanya selip padi seluas $1000 \mathrm{~m}^{2} \mathrm{di}$ lingkungan Dusun/Banjar Puseh. Selip padi ini dapat dikatakan menjadi potensi atraksi buatan karena, selip padi ini dapat menjadi lokasi perantara penyampaian cerita mengenai proses penanaman padi hingga menjadi beras menjadi lengkap sehingga dapat memberikan gambaran yang jelas kepada wisatawan dalam pelaksanaan paket wisata yang nantinya akan dikemas. Aktivitas di selip padi ini terdiri dari penjemuran biji padi dan proses selip menggunakan mesin yang berlangsung dari pukul 09.00 Wita hingga pukul 17.00 Wita.

Potensi atraksi buatan lainnya adalah adanya sanggar tari asuhan seniman tari dan lawak Bali yang sangat terkenal di Desa Batubulan Kangin yaitu Bapak I Komang Dedi Diana, S.Sn. (Dedy Tompel). Sanggar yang beliau bangun yaitu Sanggar Tari Celekontong Mas, dapat dikatakan sebagai salah satu potensi atraksi karena memiliki cerita dan misi yang sangat menarik untuk diceritakan, dimana sanggar tersebut dibangun atas dasar semangat pelestarian Tarian Bali dan misi memberikan kemudahan bagi masyarakat khususnya generasi muda untuk belajar menari Bali. Melalui adnaya sanggar tari, aktivitas belajar menari dapat pula menjadi hal yang dapat dilakukan wisatawan selama berkunjung ke 
Desa Batubulan Kangin. Area sanggar seluas lebih dari $200 \mathrm{~m}^{2}$ tersedia sebagai tempat belajar dengan berbagai fasilitas pendukung mulai dari toilet, area bermain anak, panggung pementasan, sound system dan lighting. Selain itu sanggar juga memiliki fasilitas kostum tari yang dapat dimanfaatkan bagi siswa sanggar ketika pementasan.

Potensi atraksi buatan selanjutnya adalah adanya sekolah dasar di Desa Batubulan Kangin yang dapat menjadi lokasi pengenalan sistem pendidikan dan budaya sekolah di Bali yang masih sangat kental dan berkaitan erat dengan budaya umat Hindu di Bali.

Selain adanya sekolah dasar, terdapat pula rumah produksi Jaje Sirat yang merupakan jajanan berbahan tepung ketan dan gula merah yang dibentuk seperti lingkaran benang-benang kusut. Jajanan tersebut biasa dipersembahkan dalam banten pada Upacara Yadnya masyarakat setempat dan dapat pula dinikmati langsung dengan dikombinasikan bersama pisang. Bentuk, rasa dan pembuatan yang unik dapat menjadi daya tarik bagi wisatawan untuk belajar sekaligus mencicipi jajanan khas Bali tersebut.

Potensi atraksi buatan lainnya adalah adanya sebuah landmark berupa patung selamat datang bernama Patung Dug-Dug Mong. Landmark tersebut berlokasi di lingkungan Banjar Puseh tepatnya sangat dekat dengan Pura Puseh dan Pura Desa. Landmark tersebut merupakan representasi dari budaya Dug-Dug Mong yang merupakan budaya ngiring atau mengiringi simbol-simbol Tuhan berupa Barong dan Klapakan keliling desa diiringi dengan dua jenis alat musik tradisional Gambelan yaitu terdiri dari Gambelan Kendang dan Gambelan Klemong, dimana dalam prosesi tersebut diirmakan sesuai dengan namanya yaitu "Dug-Dug Mong" secara berulang. Budaya tersebut dilangsungkan dalam enam bulan sekali.

Selain potensi atraksi buatan yang telah disebutkan sebelumnya, terdapat pula struktur rumah adat Bali yang sangat unik yaitu dibangun dengan berlandaskan nilai-nilai yang tertuang dalam Lontar Asta Kosala Kosali dimana penataan bangunan-bangunan dalam rumah disesuaikan dengan arah mata angin, karena masyarakat Hindu Bali mempercayai bahwa arah utara dan timur merupakan arah yang sakral sehingga bangunan-bangunan seperti tempat suci (Merajan), bangunan yang digunakan untuk upacara keagamaan (Bale
Dangin) serta bangunan yang diperuntukan bagi orang yang dituakan dalam keluarga, dimana bangunan-bangunan tersebut diletakan pada sisi tersebut dalam struktur rumah adat Bali. Sedangkan pada sisi barat dan selatan ditempatkan bangunan seperti toilet, kamar mandi, tempat menjemur pakaian, dapur dan lain sebagainya.

Selain penempatan bangunan struktur rumah adat Bali juga memiliki pintu masuk khusus yang dinamakan angkul-angkul beserta sebuah tembok yang disebut aling-aling di belakang pintu masuk yang menyimpan makna dan nilai filosofis yang unik dan menarik untuk diceritakan.

\section{Amenities}

Pelayanan makanan dan minuman disediakan oleh Tumang Cooking Class dengan menu makanan tradisional khas Bali seperti: 1) Appetizer: Rujak buah khas Bali; Main Course: Nasi Campur Ayam Betutu (Nasi Putih, Ayam Betutu, Sayur Urab, Satai Lilit Ayam, Pepes Ayam, Sambal Mentah dan Kacang Tanah Goreng); Nasi Campur Be Genyol (Nasi Putih, Lawar Babi, Be Genyol, Urutan, Satai Babi, Sambal Goreng); dan Nasi Campur Batuyang (Nasi Putih, Pepes Clengis, Tongkol Goreng, Sayur Daun Kelor, Sambal Goreng dan Kacang Tanah Goreng); dan Dessert: Es Salak dan Jajanan Bali

Penyediaan makanan dan minuman di Desa Batubulan Kangin dapat dilakukan di dua tempat berbeda yaitu di area Tumang Cooking Class (Lingkungan Banjar Dajan Rurung) yang menawarkan suasana makan di sebuah Rumah Adat Bali dan dapat menampung hingga 50 orang pengunjung dengan didukung oleh penyewaan set meja dan kursi. Selain area tersebut, pelayanan makanan dan minuman juga dapat disediakan oleh Tumang Cooking Class di area Sanggar Tari Celekontong Mas yang terletak di Banjar Buda Ireng, dimana suasana yang ditawarkan adalah suasana makan di area sanggar yang merupakan area belakang rumah pemiliki sanggar yaitu lebih dekat dengan alam, dikelilingi pepohonan yang rimbun dan aliran sungai di sisi timurnya sehingga memberikan suasana yang asri dan menyejukan.

\section{Accessibility}

Lokasi yang nantinya akan pertama kali dituju yaitu starting point dalam paket wisata pedesaan di Desa Batubulan Kangin yang 
terletak di pinggir Jalan Raya Celuk yaitu terhubung langsung dengan Jalan Subak Belaki menuju Desa Batubulan Kangin. Akasesibilitas menuju starting point tersebut dari Bandara Internasional Ngurah Rai sangatlah baik, dimana jalan yang akan dilalui merupakan jalan raya beraspal dilengkapi dengan garis jalan, lampu lalu lintas, papan penunjuk arah dan lebar jalan yang memadai untuk dilalui berbagai jenis kendaraan.

Aksesibilitas dari Denpasar menuju starting point maupun menuju Desa Batubulan Kangin sangatlah baik, dimana jalan yang tersedia merupakan jalan beraspal, memiliki garis jalan, papan penunjuk arah maupun papan-papan lalu lintas hingga lampu lalu lintas pun tersedia, sehingga sangat memudahkan pengendara untuk mencari lokasi desa.

Aksesibilitas yang tersedia dari Ubud hingga dapat menjangkau Desa Batubulan Kangin juga sangat baik, dimana dapat melalui dua jalur yaitu melalui Jalan Raya Sayan ataupun melalui Jalan Raya Mas. Kedua jalur tersebut menyediakan aksesibilitas yang baik, yaitu jalan beraspal dengan lebar yang memungkinkan berbagai kendaraan melintas, didukung dengan adanya lampu lalu lintas dan papan penunjuk arah sehingga dapat memudahkan pengendara untuk sampai di lokasi.

Aksesibilitas jalur paket wisata pedesaan di Desa Batubulan Kangin juga memadai yaitu jalan beraspal dengan lebar 3-5 m, dalam kondisi yang baik dan tidak berlubang.

\section{Ancillary Service}

Layanan paket wisata pedesaan di Desa Batubulan Kangin berpotensi untuk disediakan oleh masyarakat lokal setempat khsusunya masyarakat yang tergabung dalam Yayasan Celekontong Mas Batuyang dan Sri Bali TourTumang Cooking Class. Hal tersebut didukung oleh pemiliki dan pengelola kedua lembaga tersebut dimana sama-sama memiliki semangat yang tinggi, memiliki fasilitas yang memadai dan memiliki rencana-rencana pengembangan pariwisata di Desa Batubulan Kangin yang sangat ingin direalisasikan agar dapat berkontribusi pada desa serta masyarakat lainnya.

Yayasan Celekontong Mas Batuyang memiliki rencana pemanfaatan aliran sungai di sisi timur sanggar untuk pengembangan wisata tubing serta memanfaatkan lahan kosong dalam area sanggar untuk tempat pelayanan makanan dan minuman (Restoran) sehingga akan sangat dapat menunjang pengembangan pariwisata di Desa Batubulan Kangin. Sedangkan Sri Bali Tour dan Tumang Cooking Class, sangat berpotensi menjadi penyedia layanan karena telah terbukti dapat menerima kunjungan wisatawan melalui aktivitas wisata yang disediakan serta terbukti memberikan layanan yang memuaskan sehingga wisatawan yang memang sudah pernah menggunakan jasanya memberikan review yang baik dalam lamanlaman review yang ada.

Badan Usaha Miliki Desa Batubulan Kanngin dalam hal ini belum dapat dilibatkan sebagai pengelola karena adanya kekurangan sumber daya manusia sehingga BUMDes sementara baru dapat diposisikan sebagai pendukung dalam hal finansial saja, karena berdasarkan hasil wawancara dengan ketua BUMDes Batubulan Kangin yaitu Bapak Putu Andita (2020), beliau menyatakan bahwa BUMDes memiliki dana dan siap disalurkan kepada masyarakat yang memiliki usaha terutama yang juga turut mendukung pembangunan desa serta memberikan manfaat kepada masyarakat.

\section{Hospitality}

Desa Batubulan Kangin memiliki 2 desa adat yaitu Desa Adat Batuyang dan Desa Adat Batuaji dengan total sembilan banjar. Masingmasing banjar yang ada di Desa Batubulan kangin memiliki Kelompok PKK (Pemberdayaan Kesejahteraan Keluarga) yang beranggotakan ibu-ibu serta kelompok pemuda-pemudi yang biasa disebut Sekaa Teruna-Teruni (STT)

Anggota kelompok yang merupakan masyarakat lokal Desa Batubulan Kangin tersebut memiliki semangat gotong-royong yang tinggi serta memiliki ketulusan dalam mengerjakan program-program yang mendukung kepentingan bersama. Selain itu, sebagai masyarakat lokal, anggota masingmasing kelompok tersebut juga mewarisi budaya Hindu Bali yang sangat kental karena senantiasa diterapkan dalam kehidupan seharihari. Hal tersebut tercermin dari berbagai aktivitas pembuatan offering berupa canang dan gebogan yang dominan dilakukan ibu-ibu serta kesenian tari maupun menabuh yang dominan dilakukan oleh pemuda dan pemudi.

Potensi hospitality lainnya adalah adanya masyarakat di Desa Batubulan Kangin yang juga berkecimpung dalam dunia pariwisata, 
mulai dari sopir pariwisata, pemandu wisata, receptionist, house keeper, waitress restoran, bartender serta pemuda-pemudi yang juga menempuh pendidikan kepariwisataan sejak sekolah menengah hingga perguruan tinggi Potensi hospitality tersebut dapat diberdayakan dan dilibatkan dalam pemberian layanan paket wisata pedesaan di Desa Batubulan Kangin.

\section{Pengemasan Paket Wisata Pedesaan di Desa Batubulan Kangin}

Berdasarkan potensi wisata di Desa Batubulan Kangin, maka paket wisata pedesaan yang dapat dikemas adalah sebagai berikut:

\section{Half Day Cultural Cycling Tour Around Batuyang Village}

Paket wisata Half Day Cultural Cycling

Tour Around Batuyang Village merupakan sebuah paket wisata yang berfokus pada aktivitas budaya masyarakat di Desa Batuyang secara general, dimana aktivitas wisata tersebut dikemas dalam sebuah paket wisata setengah hari (half day tour) mengelilingi desa dengan bersepeda. Aktivitas wisata dirancang untuk berlangsung selama enam jam yaitu dimulai pada pukul 08.00 Wita dan berakhir pukul 14.00 Wita. Aktivitas dalam paket wisata diawali dengan penjemputan wisatawan di akomodasinya untuk diajak menuju starting point aktivitas cycling. Sesampainya di sana, wisatawan akan disambut dengan pemberian welcome drink berupa minuman khas Bali yaitu Loloh Kunyit serta pengarahan mengenai aktivitas wista yang akan dilakukan.

Lokasi yang dikunjungi dalam paket wisata ini merupakan potensi atraksi wisata di Desa Batubulan Kangin. Dimulai dari starting point di utara desa, wisatawan akan mulai diajak untuk bersepeda menyusuri Jalan Subak Belaki ditemani pemandangan sawah dan aliran sungai yang menyejukan menuju arah selatan hingga sampai pada pemberhentian pertama yaitu Pura Ulun Carik. Melalui Pura Ulun Carik, wisatawan akan diajak untuk mengenal proses penanaman padi di Bali yang sangat kental akan budaya masyarakat Hindu Bali, dimana senantiasa melibatkan prosesi keagamaan di dalamnya sejak pembajakan sawah, pembibitan, penanaman, hingga padi disimpan dalam tempat penyimpanan yang disebut jineng.

Beranjak dari Pura Ulun Carik, wisatawan akan diajak untuk melanjutkan perjalanan menuju arah selatan hingga sampai di Pura Puseh - Pura Desa Batuyang. Melalui kunjungan wisatawan ke pura tersebut, wisatawan akan diajak untuk mengenal pentingnya keberadaan pura tersebut bagi masyarakat desa maupun pentingnya dalam sebuah desa adat di Bali, serta mengenal kegiatan keagamaan yang biasa dilakukan di pura tersebut. Beranjak dari pura tersebut, wisatawan akan diajak untuk melanjutkan perjalanan menuju selatan selama kurang lebih 1 menit hingga sampai pada landmark Desa Batubulan Kangin, yaitu Patung Dug-Dug Mong. Melalui landmark tersebut, wisatawan akan diajak untuk mengenal budaya unik masyarakat, yaitu budaya Dug-Dug Mong yang merupakan budaya mengiringi (Ngiring) simbol-simbol Tuhan seperti Barong mengelilingi desa, dimana dalam budaya ngiring ini gamelan yang digunakan hanyalah dua alat musik saja yaitu Kendang dan Klemong yang diiramakan seperti nama budaya tersebut ("Dug-Dug Mong") selama ngiring berlangsung. Budaya tersebut dilakukan sebagai simbol penyucian area desa. Sebagai landmark desa yang menyimpan nilai budaya, wisatawan juga akan diajak untuk berfoto bersama di patung tersebut.

Selanjutnya, wisatawan akan diajak untuk menuju ke arah selatan untuk mengunjungi galeri wood carving yang berlokasi di area Banjar Kenanga, dimana wisatawan akan diajak untuk mengenal hasil pahatan masyarakat lokal serta mencoba memahat pola-pola sederhana yang akan diajarkan langsung oleh pemahat lokal. Beranjak dari galeri wood carving, wisatawan akan diajak untuk melanjutkan perjalanan menuju selatan yaitu mengunjungi Pura Dalem Desa Batuyang yang lokasinya berdampingan dengan kuburan desa. Melalui Pura Dalem tersebut, wisatawan akan diajak untuk mengenal pentingnya Pura Dalem dalam tatanan kehidupan masyarakat serta kaitannya dengan prosesi upacara kematian masyarakat setempat. Selanjutnya wisatawan akan diajak untuk menuju arah barat dan sedikit ke utara, yaitu mengunjungi Bale Banjar Buda Ireng. Melalui Bale Banjar tersebut, wisatawan akan diajak untuk mengenal pentingnya keberadaan Bale Banjar dalam kehidupan sosial masyarakat serta kaitannya dengan berbagai upacara keagamaan masyarakat setempat.

Beranjak dari Bale Banjar Buda Ireng, wisatawan akan diajak untuk mengunjungi Sanggar Tari Celekontong Mas yang berlokasi 
di area Bale Banjar Buda Ireng. Setibanya di sanggar tersebut, wisatawan akan disuguhkan musik bamboo tradisional yang disebut Rindik serta berbagai jajanan khas Bali sembari beristirahat menikmati kopi ataupun teh. Selain itu wisatawan akan disuguhkan pula tarian bali oleh siswa dari sanggar tari tersebut.Usai beristirahat dalam coffee break di sanggar, wisatawan akan diajak untuk melanjutkan perjalanan menuju utara, yaitu mengunjungi Sekolah Dasar Negeri 1, 2, 3 Batubulan Kangin guna mengenal sistem pendidikan di Indonesia serta budaya yang diterapkan di sekolah yang senantiasa diiringi dengan kepercayaan Hindu Bali sembari juga berinteraksi dengan warga sekolah. Selanjutnya wisatawan akan diajak untuk melanjutkan perjalanan menuju utara yaitu mengunjungi Rumah Adat Bali di area Banjar Dajan Rurung. Melalui rumah yang dikunjungi tersebut, wisatawan akan diajak untuk mengenal struktur Rumah Adat Bali yang dibangun berdasarkan peraturan dalam Lontar Asta Kosala Kosali, dimana peletakan bangunanannya dari pintu masuk hingga berbagai bangunan di dalamnya disesuaikan dengan arah mata angin serta berbagai filosofi unik di dalamnya.

Beranjak dari rumah tersebut, wisatawan akan diajak untuk menuju Griya Nengah yang lokasinya berdampingan dengan rumah tersebut. Melalui Griya tersebut, wisatawan akan diajak untuk mengenal sejarah, nilai dan fungsi keberadaan Griya di Desa Batubulan Kangin dalam kehidupan masyarakat setempat. Selain hal tersebut, wisatawan juga akan diajak untuk belajar membuat persembahan seharihari yang disebut canang serta mengenal fungsi dan nilainya dalam kehidupan masyarakat setempat.

Setelah itu, wisatawan akan diajak untuk mengunjungi Rumah Produksi Jaje Sirat yang lokasinya juga berdampingan dengan Griya tersebut. Melalui rumah produksi tersebut, wisatawan akan diajak untuk melihat proses produksi serta mencicipi Jaje Sirat yang dipadukan dengan pisang sehingga memberikan rasa yang unik. Usai mencicipi jajanan tersebut, wisatawan akan diajak untuk menuju area Tumang Cooking Class, dimana wisatawan akan disuguhkan pertunjukan memasak singkat dan diakhiri dengan makan siang yang disajikan oleh Tumang Cooking Class dengan menu makanan khas Bali. Lebih lanjut, acara wisata (Itinerary) paket wisata ini dapat dilihat dalam Tabel 2 berikut:
Tabel 2. Itinerary Paket Wisata Half Day Cultural Cycling Tour Around Batuyang Village

\begin{tabular}{|c|c|c|}
\hline Waktu & $\begin{array}{l}\text { Durasi } \\
\text { (Menit) }\end{array}$ & Kegiatan \\
\hline $08.00-09.00$ & 60 & Penjemputan \\
\hline $09.00-09.15$ & 15 & Briefing dan persiapan \\
\hline $09.15-09.20$ & 5 & Menuju Pura Ulun Carik \\
\hline $09.20-09.30$ & 10 & $\begin{array}{l}\text { Mengenal sistem irigasi } \\
\text { (Subak) dan kaitannya } \\
\text { dengan Pura Ulun Carik }\end{array}$ \\
\hline $09.30-09.35$ & 5 & $\begin{array}{l}\text { Perjalanan menuju Pura } \\
\text { Puseh dan Pura Desa } \\
\text { Batuyang }\end{array}$ \\
\hline $09.30-09.45$ & 15 & $\begin{array}{l}\text { Mengenal fungsi dan } \\
\text { pentingnya keberadaan } \\
\text { Pura Puseh dan Pura } \\
\text { Desa bagi masyarakat }\end{array}$ \\
\hline $09.45-09.46$ & 1 & $\begin{array}{l}\text { Menuju Patung Dug- } \\
\text { Dug Mong }\end{array}$ \\
\hline $09.46-09.56$ & 10 & $\begin{array}{l}\text { Mengenal Budaya Dug- } \\
\text { Dug Mong di Desa } \\
\text { Batuyang dan foto } \\
\text { bersama }\end{array}$ \\
\hline 09.56-09.59 & 3 & $\begin{array}{l}\text { Menuju Galeri Wood } \\
\text { Carving }\end{array}$ \\
\hline 09.59-10.19 & 20 & $\begin{array}{l}\text { Short Wood Carving } \\
\text { Class }\end{array}$ \\
\hline $10.19-10.24$ & 5 & $\begin{array}{l}\text { Menuju Pura Dalem dan } \\
\text { Setra Desa Batuyang }\end{array}$ \\
\hline $10.24-10.39$ & 15 & $\begin{array}{l}\text { Mengenal Pura Dalem } \\
\text { dan kaitannya dengan } \\
\text { prosesi acara kematian } \\
\text { masyarakat Hindu Desa } \\
\text { Batuyang }\end{array}$ \\
\hline $10.39-10.43$ & 4 & $\begin{array}{l}\text { Perjalanan menuju Balai } \\
\text { Banjar Buda Ireng }\end{array}$ \\
\hline $10.43-10.48$ & 5 & $\begin{array}{l}\text { Mengenal pentingnya } \\
\text { Balai Banjar dan nilai } \\
\text { Banjar dalam tatanan } \\
\text { kehidupan masyarakat }\end{array}$ \\
\hline $10.48-10.49$ & 1 & $\begin{array}{l}\text { Menuju Sanggar Tari } \\
\text { Celekontong Mas }\end{array}$ \\
\hline $10.49-11.29$ & 40 & $\begin{array}{l}\text { Coffee Break, mengenal } \\
\text { sanggar tari serta } \\
\text { menikmati musik rindik } \\
\text { dan Tarian Bali }\end{array}$ \\
\hline $11.29-11.31$ & 2 & $\begin{array}{l}\text { Menuju sekolah dasar di } \\
\text { Desa Batubulan Kangin }\end{array}$ \\
\hline $11.31-11.46$ & 15 & $\begin{array}{lr}\text { Mengenal } & \text { sistem } \\
\text { pendidikan, budaya } & \text { dalam sekolah serta } \\
\text { berinteraksi dengan } \\
\text { warga sekolah }\end{array}$ \\
\hline $11.46-11.47$ & 1 & $\begin{array}{l}\text { Menuju area Banjar } \\
\text { Dajan Rurung (Rumah } \\
\text { masyarakat) }\end{array}$ \\
\hline $11.47-12.02$ & 15 & Mengenal struktur \\
\hline
\end{tabular}




\begin{tabular}{ccl}
\hline & & $\begin{array}{l}\text { Rumah Adat Bali dan } \\
\text { nilai-nilainya dalam } \\
\text { kehidupan masyarakat } \\
\text { setempat }\end{array}$ \\
\hline $12.02-12.17$ & 15 & $\begin{array}{l}\text { Mengenal sejarah dan } \\
\text { fungsi Griya di Desa } \\
\text { Batubulan Kangin serta } \\
\text { belajar cara membuat } \\
\text { canang dan gebogan }\end{array}$ \\
\hline $12.17-12.27$ & 10 & $\begin{array}{l}\text { Mengunjungi rumah } \\
\text { produksi Jaje Sirat }\end{array}$ \\
\hline $12.27-12.57$ & 30 & $\begin{array}{l}\text { Pertunjukan memasak } \\
\text { singkat dan Mengenal } \\
\text { budaya memasak khas } \\
\text { makanan Bali }\end{array}$ \\
\hline $12.57-14.27$ & 90 & $\begin{array}{l}\text { Makan siang sembari } \\
\text { mengenalkan budaya } \\
\text { makan masyarakat Bali }\end{array}$ \\
\hline $14.00-$ Selesai & - & $\begin{array}{l}\text { Mengantar wisatawan } \\
\text { ke akomodasinya }\end{array}$ \\
\hline
\end{tabular}

Sumber: Hasil Penelitian, 2020.

Harga paket wisata ini Rp 3.544.000 hingga Rp 1.401.000. Harga tersebut didasarkan atas penghitungan biaya yang dihabiskan dalam memproduksi paket wisata tersebut serta penambahan surcharge sesuai standar yang ada. Harga paket wisata tersebut sudah termasuk berbagai penyertaan seperti transportasi sesuai dengan jumlah peserta, pemandu wisata, biaya aktivitas wisata, makan siang, coffee break, dan air mineral 1 botol per orangnya. Lebih lanjut, harga paket wisata ini dapat dilihat dalam Tabel 3 berikut:

Tabel 3. Harga Paket Wisata Half Day Cultural Cycling Tour Around Batuyang Village

\begin{tabular}{ccc}
\hline Transport & Total Pax & Price/Pax \\
\hline \multirow{3}{*}{ Avanza } & 1 & $\mathrm{Rp} 3.544 .000$ \\
\cline { 2 - 3 } & 2 & $\mathrm{Rp} 2.344 .000$ \\
\cline { 2 - 3 } & 3 & $\mathrm{Rp} 1.944 .000$ \\
\hline L300 & $4-6$ & $\mathrm{Rp} 1.761 .000$ \\
\hline ISUZU ELF & $7-9$ & $\mathrm{Rp} 1.761 .000$ \\
\hline Toyota Commuter & $10-14$ & $\mathrm{Rp} 1.482 .000$ \\
\hline Mini Bus & $15-19$ & $\mathrm{Rp} 1.393 .000$ \\
\hline Big Bus & $20-40$ & $\mathrm{Rp} 1.401 .000$ \\
\hline
\end{tabular}

Sumber: Hasil Penelitian, 2020.

\section{Days 2 Nights Tour Exploring the Authentic Way of Batuyang Village's Life}

Paket Wisata 3 Days 2 Nights Tour Exploring the Authentic Way of Batuyang Village's Life merupakan sebuah paket wisata yang akan memberikan pengalaman untuk wisatawan dapat terlibat langsung dalam kehidupan masyarakat Desa Batubulan Kangin secara lebih mendalam. Adapun aktivitas dalam paket wisata ini adalah sebagai berikut:

\section{Hari Pertama}

Aktivitas pada hari pertama, dirancang untuk berlangsung selama 6 jam 30 menit, diawali dengan penjemputan wisatawan di akomodasinya untuk diajak menuju starting point cycling hari pertama di utara desa. Sesampinya di tempat tersebut, wisatawan akan disambut dengan memberikan welcome drink berupa minuman khas Bali yaitu loloh kayu manis, sembari diberikan pengarahan mengenai berbagai hal terkait aktivitas wisata yang akan dilakukan serta menggunakan perlengkapan bersepeda dari helm hingga pelingdung siku dan lutut. Setelah persiapan selesai, cycling dimulai dengan menyusuri jalan menuju selatan ditemani pemandangan sawah dan aliran air sungai yang menyejukan. Setelah menyusuri jalan tersebut selama 5-6 menit, wisatawan akan diajak untuk singgah di Pura Ulun Carik yang berlokasi di pinggir sawah. Melalui pura tersebut, wisatawan akan diberikan pengenalan mengenai proses penanaman padi di Bali yang senantiasa seiring dengan budaya Hindu Bali sehingga sangat berkaitan dengan keberadaan Pura Ulun Carik yang merupakan stana dari Dewi Uma.

Beranjak dari Pura Ulun Carik, wisatawan akan diajak untuk melanjutkan perjalanan mnuju selatan, yaitu mengunjungi Pura Puseh-Pura Desa Batuyang. Melalui pura tersebut, wisatawan akan diperkenalkan mengenai pentingnya keberadaan pura terhadap kehidupan masyarakat di Bali serta berbagai upacara yang dilaksanakan oleh masyarakat di pura tersbut. Selanjutnya wisatawan akan diajak untuk mengunjungi landmark desa yaitu Patung Dug-Dug Mong yang berlokasi di selatan Pura. Melalui landmark tersebut, wisatawan akan diperkenalkan mengenai budaya Dug-Dug Mong yang merupakan budaya ngiring yang unik di Desa Batubulan Kangin, yaitu budaya mengiringi simbolsimbol Tuhan seperti Barong mengelilingi desa dengan gamelan Kendang dan Klemong yang diiramakan sesuai nama budaya tersebut yaitu Dug-Dug Mong. Sebagai sebuah landmark, maka di patung tersebut pula wisatawan akan diajak untuk berfoto bersama sebagai tanda bahwa memang sudah pernah mengunjungi Desa Batubulan Kangin. 
Beranjak dari landmark tersebut, wisatawan akan diajak menuju rumah masyarakat di Banjar Dajan Rurung untuk mengenal struktur Rumah Adat Bali sembari belajar memasak (Cooking Class) masakan khas Bali yaitu Ayam atau Bebek Betutu dengan beberapa menu pendamping seperti Sayur Urab, Satai Lilit, Calonpulung Ayam, Pepes Ayam, dan sambal goreng, sambal matah hingga sambal tomat. Melalui cooking class tersebut, wisatawan juga akan dikenalkan mengenai bumbu-bumbu dalam makanan khas Bali serta budaya memasak masyarakat di Bali. Setelah aktivitas cooking class selesai, maka wisatawan akan diajak untuk menikmati masakannya dalam makan siang dan rangkaian kegiatan pada hari pertama ini berakhir, lalu wisatawan akan diantarkan kembali ke akomodasinya. Lebih lanjut, acara wisata (Itinerary) Hari pertama paket wisata ini, dapat dilihat dalam Tabel 4 berikut:

Tabel 4. Itinerary Paket Wisata 3 Days 2 Nights Tour Exploring the Authentic Way of Batuyang Village's Life Hari Pertama

\begin{tabular}{|c|c|c|}
\hline Waktu & $\begin{array}{l}\text { Durasi } \\
\text { (Menit) }\end{array}$ & Kegiatan \\
\hline $08.00-09.00$ & 60 & Penjemputan \\
\hline $09.00-09.10$ & 10 & Briefing dan persiapan \\
\hline $09.10-09.15$ & 5 & Menuju Pura Ulun Carik \\
\hline $09.15-09.25$ & 10 & $\begin{array}{l}\text { Mengenal sistem irigasi } \\
\text { (Subak) dan kaitannya } \\
\text { dengan Pura Ulun Carik }\end{array}$ \\
\hline $09.25-09.30$ & 5 & $\begin{array}{l}\text { Perjalanan menuju Pura } \\
\text { Puseh dan Pura Desa } \\
\text { Batuyang }\end{array}$ \\
\hline $09.30-09.45$ & 15 & $\begin{array}{l}\text { Mengenal fungsi dan } \\
\text { pentingnya keberadaan } \\
\text { Pura Puseh dan Pura } \\
\text { Desa bagi masyarakat }\end{array}$ \\
\hline $09.45-09.46$ & 1 & $\begin{array}{l}\text { Menuju Patung Dug- } \\
\text { Dug Mong }\end{array}$ \\
\hline $09.46-09.56$ & 10 & $\begin{array}{l}\text { Mengenal Budaya Dug- } \\
\text { Dug Mong di Desa } \\
\text { Batuyang dan foto } \\
\text { bersama }\end{array}$ \\
\hline $09.56-10.00$ & 4 & 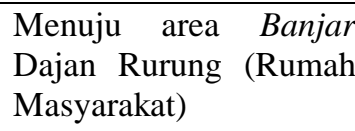 \\
\hline $10.00-10.25$ & 25 & $\begin{array}{l}\text { Mengenal struktur } \\
\text { Rumah Adat Bali dan } \\
\text { belajar membuat canang } \\
\text { dan gebogan }\end{array}$ \\
\hline
\end{tabular}

\begin{tabular}{lcl}
\hline 10.25-13.00 & 155 & Balinese cooking class \\
\hline $13.00-14.30$ & 90 & $\begin{array}{l}\text { Makan siang dengan } \\
\text { menu hasil dari cooking } \\
\text { class dan mengenal } \\
\text { budaya makan khas } \\
\text { masyarakat Bali }\end{array}$
\end{tabular}

Sumber: Hasil Penelitian, 2020.

\section{Hari Ke-2}

Aktivitas hari ke-2 juga dirancang untuk berlangsung selama 6 jam 30 menit, dimulai dengan penjemputan wisatawan di akomodasinya lalu diajak untuk menuju starting point pada hari ke-2 yaitu di area Banjar Tampad tepatnya di Pura Dalem Desa Batuyang. Sesampainya di sana, wisatawan akan disambut dengan pemberian welcome drink brupa minuman khas Bali yaitu Es Daluman sembari memberikan arahan (Briefing) bagi wisatawan mengenai aktivitas yang akan berlangsung. Setelah semua pengarahan dan persiapan perlengkapan bersepeda selesai, maka wisatawan akan diberikan pengenalan mengenai Pura Dalem serta kaitannya dengan upacara kematian masyarakat setempat. Beranjak dari Pura dalem, wisatawan akan diajak untuk melanjutkan kegiatan bersepeda menuju utara yaitu mengunjungi Balai Banjar Tampad untuk mengenal pentingnya banjar dalam kehidupan masyarakat lokal di Bali serta aktivitasaktivitas yang biasa dilakukan oleh masyarakat di tempat tersebut.

Selanjutnya, wisatawan akan diajak untuk menuju utara yaitu mengunjungi Galeri Wood Carving untuk wood carving class, dimana wisatawan selain akan diberikan pengenalan mengenai alat-alat memahat, juga akan diberikan dasar-dasar memahat hingga mencoba memahat pola-pola sederhana yang telah disediakan. Sembari aktivitas wood carving class berlangsung, wisatawan juga akan disuguhkan berbagai jajanan khas Bali dan minuman untuk menemani aktivitas wisatawan tersebut. Setelah wood carving class dan coffee break tersebut selesai, wisatawan akan diajak untuk menuju arah barat, yaitu mengunjungi Selip Padi di area Banjar Puseh, untuk mengetahui secara lebih lengkap proses padi menjadi beras.

Beranjak dari Selip Padi, wisatawan akan diajak untuk menuju selatan, yaitu mengunjungi Sanggar Tari Celekontong Mas untuk belajar menari tarian Bali lengkap dengan kaos dan kamben khas sanggar yang diberikan 
kepada wisatawan. Setelah kelas menari Bali usai, maka aktivitas wisata dalam paket wisata ini akan diakhiri dengan makan siang di area tersebut. Setelah makan siang selesai, wisatawan akan diantar kembali menuju akomodasinya. Lebih lanjut, acara wisata (Itinerary) Hari ke-2 paket wisata ini, dapat dilihat dalam Tabel 5 berikut:

Tabel 5. Itinerary Paket Wisata 3 Days 2 Nights Tour Exploring the Authentic Way of Batuyang Village's Life Hari Ke-2

\begin{tabular}{|c|c|c|}
\hline Waktu & $\begin{array}{r}\text { Durasi } \\
\text { (Menit) }\end{array}$ & Kegiatan \\
\hline $08.00-09.00$ & 60 & Penjemputan \\
\hline $09.00-09.10$ & 10 & Briefing dan persiapan \\
\hline $09.10-09.25$ & 15 & $\begin{array}{l}\text { Mengenal fungsi Pura } \\
\text { Dalem dan kaitannya } \\
\text { dengan prosesi upacara } \\
\text { kematian masyarakat } \\
\text { Hindu di Bali }\end{array}$ \\
\hline $09.25-09.30$ & 5 & $\begin{array}{l}\text { Mengenal fungsi balai } \\
\text { banjar dalam tatanan } \\
\text { kehidupan masyarakat }\end{array}$ \\
\hline 09.30-09.35 & 5 & $\begin{array}{l}\text { Menuju Galeri Wood } \\
\text { Carving }\end{array}$ \\
\hline $09.35-11.35$ & 120 & Wood carving class \\
\hline $11.35-11.55$ & 20 & Coffee Break \\
\hline $11.55-12.00$ & 5 & 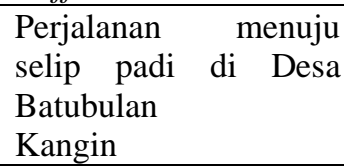 \\
\hline $12.00-12.10$ & $10 "$ & $\begin{array}{l}\text { Mengunjungi selip } \\
\text { padi untuk melihat } \\
\text { langsung proses biji } \\
\text { padi menjadi beras } \\
\text { serta mengenal } \\
\text { pemanfaatan kulit biji } \\
\text { padi }\end{array}$ \\
\hline $12.10-12.15$ & $5 "$ & $\begin{array}{l}\text { Menuju Sanggar Tari } \\
\text { Celekontong Mas }\end{array}$ \\
\hline $12.15-13.00$ & $45 "$ & $\begin{array}{l}\text { Mengenal lingkungan } \\
\text { sanggar dan belajar } \\
\text { dasar-dasar Tari Bali } \\
\text { dan Tari Puspanjali }\end{array}$ \\
\hline $13.00-14.30$ & $90 "$ & $\begin{array}{l}\text { Makan Siang sembari } \\
\text { menikmati penampilan } \\
\text { musik tradisional } \\
\text { Rindik dan Tarian Bali }\end{array}$ \\
\hline 14.30-Selesai & - & $\begin{array}{l}\text { Mengantar wisatawan } \\
\text { ke akomodasinya }\end{array}$ \\
\hline
\end{tabular}

Sumber: Hasil Penelitian, 2020.

\section{Hari Ke-3}

Hari ke-3 dalam paket wisata ini berlangsung lebih lama dari hari-hari sebelumnya, dimana wisatawan akan diajak untuk mengunjungi Rumah Produksi Jaje Sirat untuk turut serta dalam proses pembuatan Jaje Sirat dan mencicipi jajanan tersebut. Lalu, menuju Griya Nengah yang lokasinya berdampingan dengan Rumah Produksi Jaje Sirat untuk melakukan penyucian diri dengan tirta (Melukat).

Beranjak dari Griya tersebut, wisatawan akan diajak untuk mengunjungi Sekolah Dasar Negeri 1, 2, 3 Batubulan Kangin yang berlokasi di selatan Griya untuk mengenal sistem pendidikan di Indonesia serta budaya di sekolah yang ada di Desa Batubulan Kangin yang senantiasa seiring dengan budaya dan adat Agama Hindu.

Selanjutnya, wisatawan akan diajak untuk menuju selatan yaitu mengunjungi Sanggar Tari Celekontong Mas untuk terlebih dahulu mengajak wisatawan untuk mengingat kembali apa yang telah dipelajari sebelumnya sebagai persiapan pada acara penutup rangkaian paket wisata pedesaan ini. Setelah kegiatan tersebut selesai, wisatawan akan diberikan makan siang dengan menu makanan khas Bali yang disediakan oleh Tumang Cooking Class. Setelah makan siang selesai, wisatawan akan diajak untuk melakukan persiapan, yaitu make over wisatawan dari head to toe untuk tampil sebagai seorang penari Bali dalam acara farewell party.

Seperti yang telahh dipaparkan sebelumnya, pada hari ke-3 yang merupakan hari terakhir dalam rangkaian paket wisata ini menyuguhkan pengalaman spesial untuk wisatawan, dimana sebagai penutup akan diadakan sebuah farewell party yaitu sebuah acara perpisahan yang diisi dengan acara makan malam (Candle Light Dinner) sembari menikmati suguhan Tari Bali di Sanggar Tari Celekontong Mas dan menikmati hiburan lainnya.

Selain sebagai penikmat acara, wisatawan juga akan turut dilibatkan dalam memeriahkan malam perpisahan (Farewell Party) dengan ikut mementaskan Tari Bali yang sebelumnya telah dipelajari bersama siswa sanggar lengkap dengan kostum penari Bali yang tentunya akan menjadi pengalaman yang tak terlupakan bagi wisatawan.

Seluruh rangkaian kegiatan pada hari ke3 dijadwalkan untuk berakhir pada pukul 19.47 Wita dan wisatawan akan diantarkan untuk kembali ke akomodasinya. Lebih lanjut, acara wisata (Itinerary) Hari ke-3 paket wisata ini, dapat dilihat dalam Tabel 6 berikut: 
Tabel 6. Itinerary Paket Wisata 3 Days 2 Nights Tour Exploring the Authentic Way of Batuyang Village's Life Hari Ke-3

\begin{tabular}{|c|c|c|}
\hline Waktu & $\begin{array}{l}\text { Durasi } \\
\text { (Menit) }\end{array}$ & Kegiatan \\
\hline $08.00-09.00$ & 60 & Penjemputan \\
\hline 09.00-09.05 & 5 & Briefing dan persiapan \\
\hline 09.05-09.50 & 45 & $\begin{array}{l}\text { Mengunjungi rumah } \\
\text { produksi Jaje Sirat } \\
\text { dan ikut serta dalam } \\
\text { proses } \\
\text { pembuatannya }\end{array}$ \\
\hline 09.50-11.20 & 90 & $\begin{array}{l}\text { Mengenal sejarah } \\
\text { griya di Desa } \\
\text { Batubulan Kangin dan } \\
\text { melakukan proses } \\
\text { penyucian diri sesuai } \\
\text { prosesi Hindu Bali } \\
\text { (Malukat) }\end{array}$ \\
\hline $11.20-11.21$ & 1 & $\begin{array}{l}\text { Menuju sekolah dasar } \\
\text { di Desa Batubulan } \\
\text { Kangin }\end{array}$ \\
\hline $11.21-11.31$ & 10 & $\begin{array}{l}\text { Mengenal pendidikan } \\
\text { di Indonesia dan } \\
\text { mengenal budaya } \\
\text { dalam sekolah } \\
\end{array}$ \\
\hline $11.31-11.32$ & 2 & $\begin{array}{l}\text { Menuju Sanggar Tari } \\
\text { Celekontong Mas }\end{array}$ \\
\hline $11.32-11.47$ & 15 & Coffee Break \\
\hline $11.47-13.17$ & 90 & $\begin{array}{l}\text { Belajar Tari Puspanjali } \\
\text { dan gladi pementasan } \\
\text { bersama siswa Sanggar } \\
\text { Tari Celekontong Mas }\end{array}$ \\
\hline $13.17-14.47$ & 90 & Istirahat Makan Siang \\
\hline $14.47-16.47$ & 120 & $\begin{array}{l}\text { Persiapan pementasan } \\
\text { tari oleh wisatawan dan } \\
\text { siswa sanggar }\end{array}$ \\
\hline $16.47-19.47$ & 180 & $\begin{array}{l}\text { Farewell Party: } \\
1 \text { Acara pembukaan } \\
2 \text { Tari penyambutan } \\
\text { dari sanggar } \\
3 \text { Pementasan tari oleh } \\
\text { siswa sanggar dan } \\
\text { wisatawan } \\
4 \text { Makan malam } \\
5 \text { Acara hibura dan } \\
\text { ramah-tamah } \\
6 \text { Acara penutup } \\
\end{array}$ \\
\hline 19.47-Selesai & - & $\begin{array}{l}\text { Mengantar wisatawan } \\
\text { ke akomodasinya }\end{array}$ \\
\hline
\end{tabular}

Sumber: Hasil Penelitian, 2020.

\section{Harga Paket Wisata}

Paket wisata 3 Days and 2 Nights Tour Exploring the Authentic Way of Batuyang Village's Life minimal diikuti oleh empat orang wisatawan agar harga paket wisata tidak terlalu membebani wisatawan apabila jumlah wisatawan di bawah empat orang. Harga paket wisata ini berkisar antara Rp 7.719.000/orang hingga $\mathrm{Rp}$ 5.449.000/orang yang didasarkan oleh penghitungan biaya yang dihabiskan dalam memproduksi paket wisata tersebut serta penambahan surcharge sesuai standar yang ada. Lebih lanjut, harga paket wisata ini dapat dilihat dalam Tabel 7 berikut:

Tabel 7. Harga Paket Wisata 3 Days 2 Nights Tour Exploring the Autheentic Way of Batuyang Village's Life

\begin{tabular}{ccc}
\hline Transport & Total Pax & Price/Pax \\
\hline L300 & $4-6$ & Rp 7.719.000 \\
\hline ISUZU ELF & $7-9$ & Rp 6.299.000 \\
\hline Toyota Commuter & $10-14$ & Rp 5.704.000 \\
\hline Mini Bus & $15-19$ & Rp 5.372.000 \\
\hline Big Bus & $20-40$ & Rp 5.449.000
\end{tabular}

Sumber: Hasil Penelitian, 2020.

Harga paket wisata dalam Tabel 7 tersebut sudah termasuk berbagai penyertaan seperti akomodasi selama 3 malam, transportasi selama 3 hari sesuai dengan jumlah peserta, pemandu wisata, biaya aktivitas wisata, 2 kali makan siang, 2 kali coffee break, 1 kali makan malam dan air mineral. Namun, harga paket wisata tersebut belum termasuk penyertaan berupa tiket pesawat, transportasi penjemputan dari bandara menuju akomodasi maupun sebaliknya, serta pengeluaran pribadi lainnya. Transportasi penjemputan dan pengantaran wisatawan ke bandara dapat ditambah sesuai dengan permintaan.

\section{Model Saluran Distribusi Pemasaran Paket Wisata Pedesaan di Desa Batubulan Kangin}

Model saluran distribusi pemasaran yang dirancang untuk memasarkan paket wisata pedesaan di Desa Batubulan Kangin adalah model saluran distribusi pemasaran langsung yaitu melalui media digital khususnya email untuk menginformasikan kepada pelanggan sebelumnya mengenai promo maupun informasi terbaru mengenai Desa Batubulan Kangin.

Model saluran distribusi lainnya adalah saluran distribusi tak langsung yaitu melalui 
perantara dengan melibatkan agen pemasaran seperti sopir pariwisata, pemandu wisata, travel agent seperti Five Pillar Experiences, dan market places seperti GODEVI, Traveloka, Go Voyagin, maupun Tripadvisor, dimana saluran distribusi pemasaran tak langsung tersebut diperantarai dengan adanya booklet serta contract rate sebagai perjanjian penjualan paket wisata pedesaan di Desa Batubulan Kangin dengan agen-agen pemasaran tersebut. Harga yang diajukan merupakan kesepakatan dengan menambahkan besaran komisi yang telah ditentukan dalam penghitungan biaya produksi paket wisata.

\section{SIMPULAN DAN SARAN Simpulan}

Berdasarkan hasil penelitian, dapat disimpulkan bahwa:

1. Desa Batubulan Kangin memiliki potensi atraksi berupa pemandangan sawah, struktur desa adat (Pura Puseh, Pura Desa, adanya balai banjar, Pura Ulun Carik, Griya, hingga Pura Dalem dan kuburan desa), struktur Rumah Adat Bali, budaya masyarakat (Membuat persembahan atau banten berupa canang dan gebogan), hingga aktivitas Cooking Class. Potensi aksesibilitas yang tersedia memungkinkan adanya aktivitas wisata di Desa Batubulan Kangin karena dapat dijangkau oleh berbagai jenis kendaraan. Potensi amenities yang ada yaitu penyediaan makanan dan minuman khas Bali oleh Tumang Cooking Class di 2 lokasi yaitu di area Banjar Dajan Rurung dan area Banjar Buda Ireng. Potensi ancillary service yang ada yaitu layanan yang dapat diberikan oleh masyarakat lokal (Sri Bali TourTumang Cooking Class dan Yayasan Celekontong Mas Batuyang). Selain itu, potensi hospitality terdiri dari adanya PKK dan STT.

2. Potensi tersebut dikemas menjadi dua jenis paket wisata pedesaan yaitu Half Day Cultural Cycling Tour Around Batuyang Village dan 3 Days and 2 Nights Tour Exploring the Authentic Way of Batuyang Village's Life

3. Paket wisata yang dikemas akan dipasarkan melalui saluran distribusi pemasaran langsung yaitu melalui email kepada wisatawan yang telah pernah mengunjungi Desa Batubulan Kangin dan model saluran distribusi tak langsung melalui perantara agen seperti sopir pariwisata Bali, pemandu wisata Bali, Five Pillar Experiences, Go Destination Village, Traveloka, Go Voyagin dan Tripadvisor dengan menyertakan besaran komisi sesuai dengan kesepakatan

\section{Saran}

Pemerintah Desa Batubulan Kangin disarankan untuk mengembangkan wisata pedesaan karena ditemukan adanya potensi yang sangat mendukung pengadaan sebuah aktivitas wisata. Selain itu, disarankan pula untuk meningkatkan sumbr daya manusia dalam lembaga Badan Usaha Milik Desa pada bidang pariwisata, pemasaran dan teknologi informasi agar dapat semakin mendukung pengembangan paket wisata pedesaan serta meningkatkan eksistensi Desa Batubulan Kangin melalui penyediaan media-media informasi desa.

Lembaga masyarakat yang berpotensi menjadi pengelola, disarankan untuk melakukan pemetaan lebih mendalaman mengenai agen-agen perjalanan wisata yang cocok digandeng sebagai agen pemasaran paket wisata pedesaan di Desa Batubulan Kangin, serta melakukan pendekatan yang lebih mendalam kepada masyarakat dalam pengadaan paket wisata pedesaan di Desa batubulan Kangin.

Penelitian ini tentunya masih belum sempurna, maka penelitian dalam bidang sejenis kedepannya dapat melakukan penelitian secara lebih mendalaman mengenai strategi pemasaran yang tepat bagi paket wisata pedesaan di Desa Batubulan Kangin maupun di desa-desa lain yang memiliki potensi namun belum dikembangkan sehingga dapat dibantu dengan melakukan penelitian sejenis. 


\section{Kepustakaan}

Afriza, Lia, Anti Riyanti dan Septy Indrianty. 2017. Pengembangan Pariwisata Kawasan Gede Bage Berbasis Ekowisata. Tourism and Hospitality Essetials Journal. Vol 7/2. pp 53-64. Stiepar Yapari Aktripa Bandung.

Ariani, Vitria. 2017. Pengembangan Desa Wisata (Desa Membangun Indonesia). Bumdes.id. Diakses tanggal 22 September 2019.

Arismayanti, Ni Ketut, I Made Sendra, I Ketut Suwena, Made Budiarsa, I Made Bakta, dan I Gde Pitana. 2019. Tourism Villages' Development in Bali, Mass or Alternative Tourism. Journal of Tourism and Hospitality Management. Vol 7/2. pp 117-139. American Research Institute for Policy Development.

Bali Travel News. 2017. Atasi Ketimpangan, Gianyar Susun Zona Pengembangan Pariwisata. (balitravelnews.com/2017/02/08/atasiketimpangan-gianyar- susun-zonapengembangan-pariwisata/, diakses tanggal 22 September 2019)
Deny, Septian. 2019. Gianyar Ditetapkan sebagai Kota Kerajinan Dunia. (https://www.liputan6.com/bisnis/read/3 947059/gianyar-ditetapkan- sebagaikota-kerajinan-dunia, diakses tanggal 22 September 2019).

Dewi, Ni Gusti Ayu Susrami dan Luh Gede Leli Kusuma Dewi. 2016. Paket Wisata Pedesaan "Become Pangsanian” di Desa Wisata Pangsan, Petang, Badung. Jurnal Analisis Pariwisata. Vol 16/1. pp 35-51. OJS Unud.

Mahagangga, I Gst. Ag. Oka, dkk. 2015. Kajian Pengembangan Desa Wisata di Kabupaten Badung. Jurnal Seminar Nasional Sains dan Teknologi (Senastek).

Patriella, Yanita. 2019. 2019, Indonesia Ditargetkan Punya 2000 Desa Wisata. (https://ekonomi.bisnis.com/read/20190 715/12/1124347/2019-indonesiaditargetkan-punya-2.000-desa-wisata, diakses tanggal 22 Spetember 2019).

Suwena, I Ketut dan I Gst Ngr Widyatmaja. 2017. Pengetahuan Dasar Ilmu Pariwisata. Denpasar: Udayana Press. 